24. Патент Российской Федерации № 2484125 Способ изготовления топливных брикетов из биомассы (С1) МПК C10L5/44, C10L5/14, C10F7/06. / Табакаев Р. Б., Заворин А. С., Казаков А. В., Плахова Т. М.; заявл. 16.04.2012; опубл. 10.06. 2013. Бюл. № 16. -7 c.

25. Pat. WO 2011062488 A1 IPC C10L5/44 Fuels pellets, their preparation and use / Meneva B.V., Renirie J.G., Van Der Meijden J. A. A., Van Soest J. J.G., Plijter J.J.; publ. 26.05.2011.

26. Pat. US 20130031830 (A1) IPC C10L11/06; C10L5/04 Method for producing binders and combustible composite materials and composition produced therefrom / Philip H. Steel, Venkata K. Penmetsa; publ. 07.02.2013.

27. Борисов Ю. Европейское качество // Леспроминформ, 2004, №9. - С. 86-87.

28. Доня, Д.В. Инженерная реология: учебное пособие. / Д.В. Доня, А.А. Леонов. - Кемерово: Кемеровский технологический институт пищевой промышленности. - 2008. - 123 c.

Надійшла 25.10.2018. До друку 02.11.2018. Рецензія 30.10.18

Адреса для переписки:

ОНАХТ, вул. Канатна, 112, м. Одеса, 65039

\title{
USE OF BIOLOGICALLY ACTIVE SUBSTANCES OF THE HYDROLASE CLASS IN COMPOUND FEED FOR PIGS
}

\begin{abstract}
The high efficiency of poultry and pigs is based on high-yielding breeds, balanced high-yielding mixed fodders and appropriate animal holding conditions. Recently, the tendency of increasing the efficiency of the nutritional potential of mixed fodder has become of increasing importance in order to reduce the cost of this factor in the production of livestock products.

The role of the intermediate link between animals and the nutritional potential of feed is borne by enzymes. A few years ago the question about the use of exogenous enzyme preparations in the composition of feed was controversial. But a better understanding of the action of industrial enzymes, as well as more successfully developed enzyme preparations have changed the situation. Enzymes are now widely used in many countries around the world to improve the quality of feed produced on the basis of barley, wheat, wheat and barley, as well as other cereals.

Perspective is the use of enzyme preparations in ration of young pigs in fattening. In our experiments, lysozyme was used to improve the productivity of young pigs. The experiments were carried out at "Iziumsky compound feed plant", Izium district, Kharkiv region and at the farm "Avangard-D" Ltd., Ovidiopolsky district, Odesa region.

It was established that feeding of young pigs of mixed fodder enriched with the enzyme preparation "Lysozyme" prevents the growth of average daily increments, live weight of animals and reduction of feed costs per unit of products.

The lowest feed costs per unit gain of live weight were set in the experimental group, which comprised 4.2 feeds. unit. That is less in comparison with animals of control group I by $7.0 \%$.

The economic efficiency of raising the young from 4 to 8 months of age has shown that the addition of prezime "lysozyme" to the diet of pigs affects the formation of basic expenses and the receipt of net profit per 1 head.

Key words: feeding, pig, productivity, premix, enzyme preparation "Lysozyme".
\end{abstract}

\section{Formulation of the problem}

In the digestive tract, animals and poultry contain specialized hydrolytic enzymes that split various nutrients - starch, sugars, fats and proteins, but almost no enzymes that can digest cellulose and other carbohydrates. Meanwhile, fiber creates walls of plant cells, which are not completely destroyed when crushing fodder.

Proteins and carbohydrates that are inside whole cell membranes are not available for animal enzymes. If, however, the enzymes that hydrolyze cellulose add to the feed, they begin to work in the intestines together with animal enzymes, which will provide access to valuable nutrients that would be worse off if they were lost to the body. In addition, grain of cereals - wheat, barley, oats, rye - contains a large amount of soluble fiber, which is an anti-nutrient factor. Soluble cellulose forms a highdensity gel in the intestines, resulting in a decrease in the activity of the body's own enzymes, complications of absorption, increasing the risk of developing pathogenic microbes. These negative effects can be prevented by adding feed enzymes that destroy soluble fiber, thus lowering the density of the contents of the intestines. It should also be taken into account that in the early stages of development and under stress, normal secretion of digestive enzymes is suppressed. The deficiency of enzyme activity can be prevented by adding feed enzymes [1].

The proposed method of using the enzyme preparation "Lysozyme" is based on increasing the live weight of pigs and young pigs on fattening.

Enzyme preparations are introduced into an organism of animals and are intensively included in biochemical processes, accelerating the process of decomposition of synthesis and assimilation of fodder proteins, fats and carbohydrates into simple easily assimilated forms and thereby increase the digestibility of feed. As a result of intensive processes of absorption of products of decomposition of feed in the body there is a higher synthesis. 
Based on these preconditions, we set ourselves the task of increasing the digestibility of feed, which is a prerequisite for increasing the live weight of pigs and young pigs, by introducing the enzyme preparation "Lysozyme" into the diet . In this regard, the study of "Lysozyme" in feeding pigs is of great scientific and practical importance.

\section{Analysis of recent research and publications.}

Lysozyme is a widespread enzyme in nature. It is widely distributed in plants and organisms of animals, body fluids and secretions, it can dissolve bacterial cells and quickly cleanse the mucous membrane, thus accelerating the recovery and increase of anti-infectious abilities [2,3].

Setting up tasks. Goal the research was to study the effect of the enzyme preparation "Lysozyme" on the growth and development of young pigs on fattening. The experiment was conducted at the farm of «Avangard-D» Ltd, Ovidiopolskiy district, Odessa region.

In this regard, we were assigned the following tasks:
- to determine the effect of different doses of «Lysozyme» on the growth and development rates of young pigs;

- to determine the effect of the enzyme preparation on the feed costs during the fattening period from the age of 4 months to slaughter;

- to establish the economic efficiency of using the investigated enzyme preparation in pigs rations.

An example of implementing a method for feeding young pigs according to the scheme is presented in Table 1. Access to water was free without restrictions. The data of the combined feed are given in Table 2 .

To conduct the experiment was conducted equalization period. Subsequently, a test group of young pigs was formed for 12 heads, taking into account breed, origin, age and live weight. Dietary rations between the groups on the set of feeds differed in the amount of enzyme preparation "Lysozyme", which is introduced into the composition of compound feed by spraying. The nutrition diet meets the requirements of the new detailed rules $[4,5]$

Table 1 - Scheme of experiment

\begin{tabular}{||c||c||c||c||}
\hline Animal Groups & $\begin{array}{c}\text { Age of animals } \\
\text { (days) }\end{array}$ & $\begin{array}{c}\text { Number of animals in the } \\
\text { group, heads }\end{array}$ & Characteristics of feeding \\
\hline \hline I control & 120 & 12 & Basic diet (BD) \\
\hline \hline II experimental & 120 & 12 & Mixed fodder with «Lysozyme» \\
\hline
\end{tabular}

Table 2 - One Kg is contained

\begin{tabular}{|c|c|c|c|c|c|c|c|c|}
\hline Indicator & 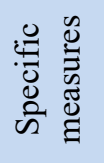 & $\stackrel{\mathbb{N}}{\pi}^{\pi}$ & 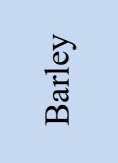 & 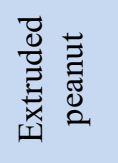 & 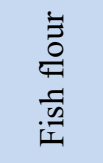 & 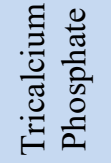 & $\frac{ \pm}{\tilde{N}}$ & $\stackrel{\frac{\pi}{0}}{\circ}$ \\
\hline $\begin{array}{l}\text { A recipe for full-fat feed for } \\
\text { fattening }\end{array}$ & $\%$ & 41 & 44 & 8 & 5 & 0,5 & 0,5 & \\
\hline Feed Units & FU & 0,513 & 0,528 & 0,097 & 0,053 & & & 1,191 \\
\hline Exchange energy & MJ & 5,315 & $5,5,776$ & 0,915 & 0,625 & & & 12,631 \\
\hline Dry substance & $\mathrm{Kg}$ & 0,39 & 0,33 & 0,09 & 0,04 & 4,68 & & 10,35 \\
\hline Raw protein & $\mathrm{g}$ & 37,6 & 49,7 & 14,6 & 36,0 & & & 137,9 \\
\hline Permeated protein & $\mathrm{g}$ & 28,11 & 38,50 & 11,7 & 33,18 & & & 111,49 \\
\hline Crude fiber & $\mathrm{g}$ & 11,20 & 25,96 & 4,20 & & & & 41,36 \\
\hline Lizin & $\mathrm{g}$ & 1,140 & 1,710 & 0,899 & 2,821 & & & 6,57 \\
\hline Methionine + Cystine & $\bar{g}$ & 1,096 & 1,730 & 0,506 & 1,192 & & & 4,524 \\
\hline Calcium $(\mathrm{Ca})$ & $\bar{g}$ & 0,730 & 0,550 & 0,232 & 3,882 & 1,406 & & 6,80 \\
\hline Phosphorus (P) & $\overline{\mathrm{g}}$ & 1,08 & 1,52 & 0,40 & 1,95 & 0,86 & & 25,81 \\
\hline Iron $(\mathrm{Fe})$ & $\mathrm{mg}$ & 14,7 & 45,2 & 11,2 & 5,8 & & & 76,9 \\
\hline Copper & $\mathrm{mg}$ & 1,398 & 0,853 & 0,42 & 0,889 & & & 3,56 \\
\hline Zinc & $\mathrm{mg}$ & 8,990 & 16,128 & 1,836 & 6,137 & & & 33,091 \\
\hline Manganese ( Mn ) & $\mathrm{mg}$ & 7,110 & 77,559 & 0,810 & 1,398 & & & 16,877 \\
\hline Cobalt (Co) & $\mathrm{mg}$ & 0,203 & 0,115 & 0,027 & 0,004 & & & 0,389 \\
\hline$\overline{\text { Iodine }(\mathrm{Y})}$ & $\overline{\mathrm{mg}}$ & 0,053 & 0,089 & $\begin{array}{c}0,017 \\
\end{array}$ & 0,128 & & & 0,287 \\
\hline
\end{tabular}


Feeding and keeping the animals of the comparative groups were the same, feeding the animals twice a day with granulated feed.

\section{Presentation of the main research material.}

During the experiment, we stated:

- change in live weight of the body and daily average increments by individual weighing of animals at the age of 4-5-6-7 months;

- $\quad$ feed costs for $1 \mathrm{Kg}$ increase in live weight of animal.

The average daily increments of animals of different ages, and the results of using the method of feeding the young pigs are given in Table 3 .

These data show that the highest live weight of animals in 7 months of age was received in the second experimental group that received feed with "Lysozyme".

The consumption of feed per unit increment of live weight is closely related to the overall biological value of the diet. The lowest amount of feed per unit of growth in live weight was established in the II experi- mental group, which comprised 4,2 feeds unit. That is less in comparison with animals of I control group by $7,0 \%$.

Economic efficiency rearing of 4 to 8 months of age showed that the additive premix "Lizotsymom" to the diet of pigs influences the formation of fixed costs and obtain net income per 1 head. Economic indicators are given in Table 4. The highest effect on growth and development of animals was obtained during feeding mixed fodder with the enzyme preparation "Lysozyme", which in the digestive tract increases the availability of nutrients of fodder fed young pigs:

- from sales of one head products from the first group received $4720,00 \mathrm{UAH}$, II 5120,00 UAH;

- the net profit from the raising of animals in the control group amounted to 3638,60 $\mathrm{UAH}$, in the II experimental group 4023,40 $\mathrm{UAH}$

- $\quad$ the level of profitability of production was: I - $30 \%$, II $-45,5 \%$.

Table 3 - Dynamics of live weight and average daily increments of pigs for growing period from 4 to 8 months of age $(n=12), X \pm S_{\mathrm{x}}$

\begin{tabular}{|c|c|c|c|c|c|}
\hline \multirow{2}{*}{$\begin{array}{l}\text { A group of } \\
\text { animal }\end{array}$} & \multirow{2}{*}{ Indicator } & \multirow{2}{*}{$\begin{array}{c}\text { When deciding } \\
\text { on a trial }\end{array}$} & \multicolumn{3}{|c|}{ Age, month } \\
\hline & & & 5 & 6 & 7 \\
\hline \multirow{4}{*}{ I control } & live weight, $\mathrm{kg}$ & $42,0 \pm 0,320$ & $60,0 \pm 0,300$ & $82,0 \pm 0,125$ & $101,0 \pm 0,510$ \\
\hline & absolute growth, $\mathrm{kg}$ & - & $18,0 \pm 0,490$ & $99,0 \pm 0,200$ & $19,0 \pm 0,295$ \\
\hline & average daily, $\mathrm{g}$ & - & $626,0 \pm 20,20$ & $730,0 \pm 6,25$ & $680,0 \pm 19,00$ \\
\hline & $\%$ to control & - & - & - & - \\
\hline \multirow{4}{*}{$\begin{array}{l}\text { II experi- } \\
\text { mental }\end{array}$} & live weight, $\mathrm{kg}$ & $42,0 \pm 0,295$ & $62,0 \pm 0,300$ & $86,0 \pm 0,400$ & $106,0 \pm 0,400$ \\
\hline & absolute growth, kg & - & $20,0 \pm 0,600$ & $24,0 \pm 0,500$ & $20,0 \pm 0,355$ \\
\hline & average daily, g & - & $689,0 \pm 12,0$ & $800 \pm 19,0$ & $714,0 \pm 12,0$ \\
\hline & $\%$ to control & - & 110,0 & 109,5 & 105,0 \\
\hline
\end{tabular}

Table 4 - The economic efficiency of raising young piglets from 4 to 7 months of age

\begin{tabular}{||l||c||c||}
\hline \multicolumn{1}{|c||}{ Indicator } & I control & II experimental \\
\hline \hline Number of animals in the group & 12 & 12 \\
\hline \hline Growth on the 1st head during growing, kg & 59 & 64 \\
\hline \hline Consumption of food, kg & 421,0 & 224,0 \\
\hline \hline For 1 kg of gain, feed units & 265,5 & 4,2 \\
\hline \hline The cost of feed per kg, all feed unit & 435,0 & 268,8 \\
\hline \hline The cost of 1 cwt mixed fodder, UAH & 1081,35 & 436,0 \\
\hline \hline Total expenses for the cultivation of one head, UAH & 961,35 & 1096,6 \\
\hline \hline Including feed, UAH & 43,0 & 976,6 \\
\hline \hline Salary, in UAH & 80,0 & 40,0 \\
\hline \hline Other expenses, UAH & 4720,0 & 80,0 \\
\hline \hline Revenue from realization of growth in one animal, UAH & 3638,6 & 5120,0 \\
\hline \hline Profit from sales of one animal, UAH & 43663,2 & 4023,4 \\
\hline \hline Profit from the sales growth of an animal group, UAH & 30,0 & 48280,8 \\
\hline \hline Profitability level, \% & & 45,5 \\
\hline \hline
\end{tabular}


Conclusions.

Thus, the proposed method of feeding young pigs of mixed fodder enriched with the enzyme preparation "Lysozyme" prevents an increase in average daily increments, live weight of animals and a decrease in feed costs per unit of products.

\title{
REFERENCES
}

1. Egorov B.V. Production technology of premixes. Textbook. / B. V. Egorov, O. I. Shapovalenko, A. V. Makarynska. - Kyiv: Center for Educational Literature, 2007. - 288 p.

2. Genkel P. A. Microbiology with the basics of virology. / P. A. Henkel. - SPb: SpetsLit, 2002. - 591 p.

3. Medical microbiology, virology, immunology. L. B. Borisov, A. M. Smirnov, I. S. Freidlin. - Moscow: Medicine, 1994. $408 \mathrm{p}$.

4. Svezhentsov A. I. Normified feeding of pigs / A.I. Svezhenetsov, R. Y. Kravtsev, Y. I. Pivtorak. - Lviv., 2005. - 385 p.

5. Feeding of farm animals / Edited by I. I. Ibatullina. - Vinnytsya., 2007. -612 p.

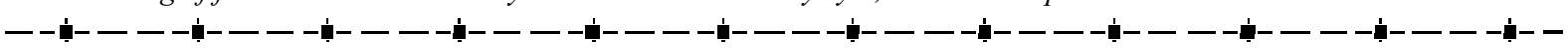

О.Й. КАРУНСБКИЙ, д-р с.-г. наук, професор С.О. ЦХХОВСКИЙ, студент

Одеська націіональна академія харчових технологій, Одеса

\section{ВИКОРИСТАННЯ БІОЛОГІЧНО АКТИВНИХ РЕЧОВИН КЛАСУ ГІДРОЛАЗ У КОМБІКОРМАХ ДЛЯ СВИНЕЙ}

\begin{abstract}
Анотація
Висока ефективність птиці та свиней трунтується на високоврожайних породах, збалансованих високопродуктивних комбікормах та відповідних умовах утримання тварин. Останнім часом зростає тендениія до підвищення ефективності харчового потенціалу комбікормів для зниження вартості иього фактора у виробництві продукції твариннищтва. Роль проміжної ланки між тваринами і поживним потенціалом корму переносяться ферментами. Кілька років тому питання про використання екзогенних ферментних препаратів у складі кормів було спірним. Але краще розуміння дї промислових ферментів, а також більш успішно розроблених ферментних препаратів змінили ситуацію.

Ферменти в даний час широко використовуються у багатьох краӥнах світу для поліпшення якості кормів, вироблених на основі ячменю, пшениці, пшениці і ячменю, а також інших зернових культур. Перспективним є використання ферментних препаратів у раціоні молодняку свиней у відгодівлі.

В роботі використовували препарат лізоцима для підвищення продуктивності молодняку свиней. Досліди проводилися на Ізюмському комбікормовому заводі Ізюмського району Харківської області та на фермі ТОВ «Авангард-Д», Овідіопольський район, Одеська область.

Встановлено, щзо згодовування молодняку свиней комбікорма, збагаченого ферментним препаратом «Лізоиим» запобігає зростанню середньодобових приростів, живої маси тварин та зниженню витрат корму на одиницю продукиї.

Найменші витрати кормів на одиницю приросту живої маси були встановлені в піддослідній групі що склало - 4,2 корм. од., що менше в порівнянні з тваринами I контрольної групи на 7,0\%.

Економічна ефективність вирощування молодняку з 4 до 8 місячного віку показала що добавка преміксу "Лізочимом" до рачіону свиней впливає на формування основних витрат та отримання чистого прибутку в розрахунку на 1 голову.
\end{abstract}

Ключові слова: годівля, свиня, продуктивність, премікс, ферментний препарат "Лізоцим".

\section{ЛІТЕРАТУРА}

1. Егоров Б.В. Технологія виробництва преміксів. Підручник. / В. В. Сгоров, О. І. Шаповаленко, А. В. В. Макаринська. - Київ: Центр освітньої літератури, 2007. - 288 с.

2. Генкель П. А. Мікробіологія з основами вірусологї. / П. А. Хенкель. - СПб: Спеиліт, 2002. - 591 c.

3. Медична мікробіологія, вірусологія, імунологія. Л. Б. Борисов, А. М. Смирнов, І. С. Фрейдлін. - М .: Медицина, 1994. - 408 c.

4. Свіженцов А. I. Нормований підживлення свиней / А.І. Свегенецов, Р. Я. Кравиев, Ю. І. Півторак. Львiв., 2005. - $385 c$.

5. Годування сільськогосподарських тварин / Під редакцією I. І. Ібатулліної. - Вінниия., 2007. - 612 с.

Надійила 11.11.2018. До друку 28.11.2018. Рецензія 20.11.18 